\title{
Mathematical modeling of pequi pulp drying and effective diffusivity determination ${ }^{1}$
}

\author{
Elisabete P. de Sousa ${ }^{2}$, Rossana M. F. de Figueirêdo ${ }^{2}$, Josivanda P. Gomes ${ }^{2}$, \\ Alexandre J. de M. Queiroz ${ }^{2}$, Deise S. de Castro ${ }^{2}$ \& Danielle M. Lemos ${ }^{2}$ \\ ${ }^{1}$ Part of the PhD Thesis of the first author in the Postgraduate Course in Agricultural Engineering \\ ${ }^{2}$ Universidade Federal de Campina Grande/Centro de Tecnologia e Recursos Naturais/Unidade Acadêmica de Engenharia Agrícola. Campina Grande, \\ PB. E-mail: elisabete_pianco@yahoo.com.br; rossana@deag.ufcg.edu.br; josivanda@gmail.com (Corresponding author); alex@deag.ufcg.edu.br; \\ deise_castro01@hotmail.com; daniele_jua@yahoo.com.br
}

Key words:

Caryocar coriaceum Wittm thickness

convective drying

\begin{abstract}
A B S T R A C T
The aim of this work was to study the drying kinetics of pequi pulp by convective drying at different conditions of temperature $\left(50,60,70\right.$ and $\left.80^{\circ} \mathrm{C}\right)$ and thickness $(0.5,1.0$ and $1.5 \mathrm{~cm}$ ) at the air speed of $1.0 \mathrm{~m} \mathrm{~s}^{-1}$, with no addition of adjuvant. The experimental data of pequi pulp drying kinetics were used to plot drying curves and fitted to the models: Midilli, Page, Henderson \& Pabis and Newton. Effective diffusivity was calculated using the Fick's diffusion model for a flat plate. It was found that, with increasing thickness, the drying time increased and, with increasing temperature, the drying time was reduced. The Midilli model showed the best fit to the experimental data of pequi pulp drying at all temperatures and thicknesses, presenting higher coefficients of determination $\left(\mathrm{R}^{2}\right)$, indicating that this model satisfactorily represents the pequi pulp drying phenomenon. There was a trend of increase in the effective diffusivity with the increase in pulp layer thickness and temperature.
\end{abstract}

\section{Palavras-chave:}

Caryocar coriaceum Wittm espessura secagem convectiva

\section{Modelagem matemática da secagem da polpa de pequi e determinação da difusividade efetiva}

\begin{abstract}
R E S U M O
Objetivou-se, neste trabalho, estudar a cinética de secagem da polpa de pequi por meio da secagem convectiva em diferentes condições de temperatura $\left(50,60,70\right.$ e $\left.80^{\circ} \mathrm{C}\right)$ e espessura $(0,5 ; 1,0$ e $1,5 \mathrm{~cm})$ na velocidade do ar $1,0 \mathrm{~m} \mathrm{~s}^{-1}$, sem adição de adjuvante de secagem. Com os dados experimentais da cinética de secagem da polpa de pequi foram traçadas curvas de secagem cujos modelos ajustados aos dados experimentais, foram: Midilli, Page, Henderson e Pabis e Newton. Calculou-se a difusividade efetiva utilizando o modelo difusivo de Fick para uma placa plana. Constatou-se que, com o aumento da espessura, o tempo de secagem aumentou e com o aumento da temperatura o tempo de secagem foi reduzido. O modelo de Midilli foi o que melhor se ajustou aos dados experimentais da secagem da polpa de pequi, em todas as temperaturas e espessuras, por apresentar maior coeficiente de determinação $\left(\mathrm{R}^{2}\right)$, indicando que este modelo representa satisfatoriamente o fenômeno de secagem da polpa de pequi. Foi evidenciado que houve tendência de aumento da difusividade efetiva com o aumento da espessura da camada da polpa e com o aumento da temperatura.
\end{abstract}




\section{INTRODUCTION}

Pequi is popularly known as 'pequi', 'piqui', 'pequiá', 'amêndoa de espinho', 'grão de cavalo' or 'amêndoa do Brasil'. It adapts to the most diverse ecological conditions, playing an important role in the life of the inhabitants of these regions, and its fruit can be marketed or even used for consumption. It has high value as food, timber, medicine, ornamental and in the production of honey and oil, among others (Damiani et al., 2013; Carlos et al., 2014).

The obtainment of products from the pequi pulp in the market requires techniques and equipment adequate to the fruit, besides the knowledge on its chemical and physicochemical characteristics. It should be pointed out that there are still few studies on the species Caryocar coriaceum (Oliveira et al., 2010).

In pulp powders, the quality and lifespan strongly depends on the moisture content, which has influence on palatability, digestibility, physical structure and handling (Alexandre et al., 2007). To reduce the moisture content of the foods, it is appropriate to perform the drying process, which, besides prolonging the shelf life, significantly reduces the costs of certain operations such as packaging, transport and storage, which consequently increases the commercial value of the product (Resende et al., 2012). However, the selection of the conditions of the drying operation (temperature, type of drying and time) influences the alterations of the product, given its importance to obtain quality products (Aquino et al., 2009).

According to Dionello et al. (2009), the drying characteristics of any product, including the evaluation of mathematical models that better describe the process, are important in the selection and development of equipment and in the calculation of the operational costs. In this context, this study aimed to verify the mathematical modeling and calculate the effective diffusivity of pequi pulp under different conditions of temperature and thickness.

\section{Material AND Methods}

The experiment was carried out at the Laboratory of Storage and Processing of Agricultural Products (LAPPA), of the Academic Unit of Agricultural Engineering (UAEA), at the Center of Technology and Natural Resources (CTRN) of the Federal University of Campina Grande (UFCG), located in the municipality of Campina Grande-PB, Brazil $\left(7^{\circ} 15^{\prime} 18^{\prime \prime}\right.$ S; $35^{\circ} 52^{\prime} 28^{\prime \prime} \mathrm{W} ; 550 \mathrm{~m}$ ).

The raw material was pequi (Caryocar coriaceum Wittm) pulp and the fruits were purchased in the municipality of Crato-CE.

Pequi pulp drying was performed in triplicate, in a forced-air oven, at temperatures of $50,60,70$ and $80^{\circ} \mathrm{C}$, with pulp layer thicknesses of $0.5,1.0$ and $1.5 \mathrm{~cm}$, air speed of 1.0 $\mathrm{m} \mathrm{s}^{-1}$ and drying air relative humidity of 20, 13, 8 and 5\%, respectively. Pequi pulp was evenly spread on stainless-steel rectangular trays $(24.5 \times 16.5 \mathrm{~cm})$ forming a thin layer with the different thicknesses. During the drying processes, the trays were weighed at regular time intervals until constant weight. The experimental data were used to calculate the values of moisture ratio according to Eq. 1. After drying, the samples were removed from the trays using a stainless-steel spatula and ground in a processor to obtain the powder.

$$
\mathrm{RX}=\frac{\mathrm{M}-\mathrm{M}_{\mathrm{e}}}{\mathrm{M}_{\mathrm{i}}-\mathrm{M}_{\mathrm{e}}}
$$

where:

RX - moisture ratio, dimensionless;

M - moisture content of the product, d.b.;

$\mathrm{Me}$ - equilibrium moisture content, d.b.; and,

Mi - initial moisture content, d.b.

Table 1 shows the mathematical models fitted to the pequi pulp drying curves using nonlinear regression through the Quasi-Newton method, employing the computational program Statistica 7.0 (Statsoft, 2007).

Table 1. Mathematical models used in the modeling of pequi pulp drying

\begin{tabular}{llc}
\hline Designation of the model & \multicolumn{1}{c}{ Model } & Equation \\
Midilli & $\mathrm{RX}=\mathrm{a} \exp \left(-\mathrm{k} \mathrm{t}^{\mathrm{n}}\right)+\mathrm{bt}$ & $(2)$ \\
Page & $\mathrm{RX}=\exp \left(-\mathrm{k} \mathrm{t}^{\mathrm{n}}\right)$ & $(3)$ \\
Henderson \& Pabis & $\mathrm{RX}=\mathrm{a} \exp (-\mathrm{k} \mathrm{t})$ & $(4)$ \\
Newton & $\mathrm{RX}=\exp (-\mathrm{k} \mathrm{t})$ & $(5)$ \\
\hline
\end{tabular}

$\mathrm{RX}$ - Moisture ratio of the product, dimensionless; $k$ - Drying constants, min; $a, b, n$ Coefficients of the models; $t$ - Drying time, min

The best model was selected based on the following criteria: highest determination coefficient $\left(\mathrm{R}^{2}\right)$, lowest mean squared error (MSE) (Eq. 6) and distribution of residuals.

$$
\mathrm{MSE}=\sqrt{\frac{\sum\left(\mathrm{RX}_{\mathrm{pred}}-\mathrm{RX}_{\mathrm{exp}}\right)^{2}}{\mathrm{n}}}
$$

where:

MSE - mean squared error;

$\mathrm{RX}_{\text {pred }}$ - moisture ratio predicted by the model;

$\mathrm{RX}_{\text {exp }}$ - experimental moisture ratio; and,

n - number of observations.

Effective diffusivity or diffusion coefficient $\left(\mathrm{D}_{\mathrm{EF}}\right)$ was determined using the Fick's diffusion model for a flat plate with $\mathrm{n}=4$, according to Eq. 7 .

$$
\mathrm{RX}=\left(\frac{8}{\pi^{2}}\right) \sum_{\mathrm{n}=0}^{\infty} \frac{1}{(2 \mathrm{n}+1)^{2}} \exp \left(-\frac{(2 \mathrm{n}+1)^{2}}{4} \pi^{2} \frac{\mathrm{D}_{\mathrm{EF}} \mathrm{t}}{\mathrm{L}_{0}^{2}}\right)
$$

where:

RX - moisture ratio, dimensionless;

$D_{E F}$ - effective diffusivity, $\mathrm{m}^{2} \mathrm{~s}^{-1}$;

$\mathrm{L}_{0} \quad$ - pulp thickness, cm;

$\mathrm{n}$ - number of terms of the equation; and,

t $\quad$ time, s.

\section{Results AND Discussion}

Table 2 shows the adjustment parameters of the mathematical models Midilli, Page, Henderson \& Pabis and Newton fitted to 
Table 2. Adjustment parameters of the mathematical models Midilli, Page, Henderson \& Pabis and Newton with their respective determination coefficients $\left(R^{2}\right)$, mean square errors (MSE) and distribution of residuals (DR) of pequi pulp drying

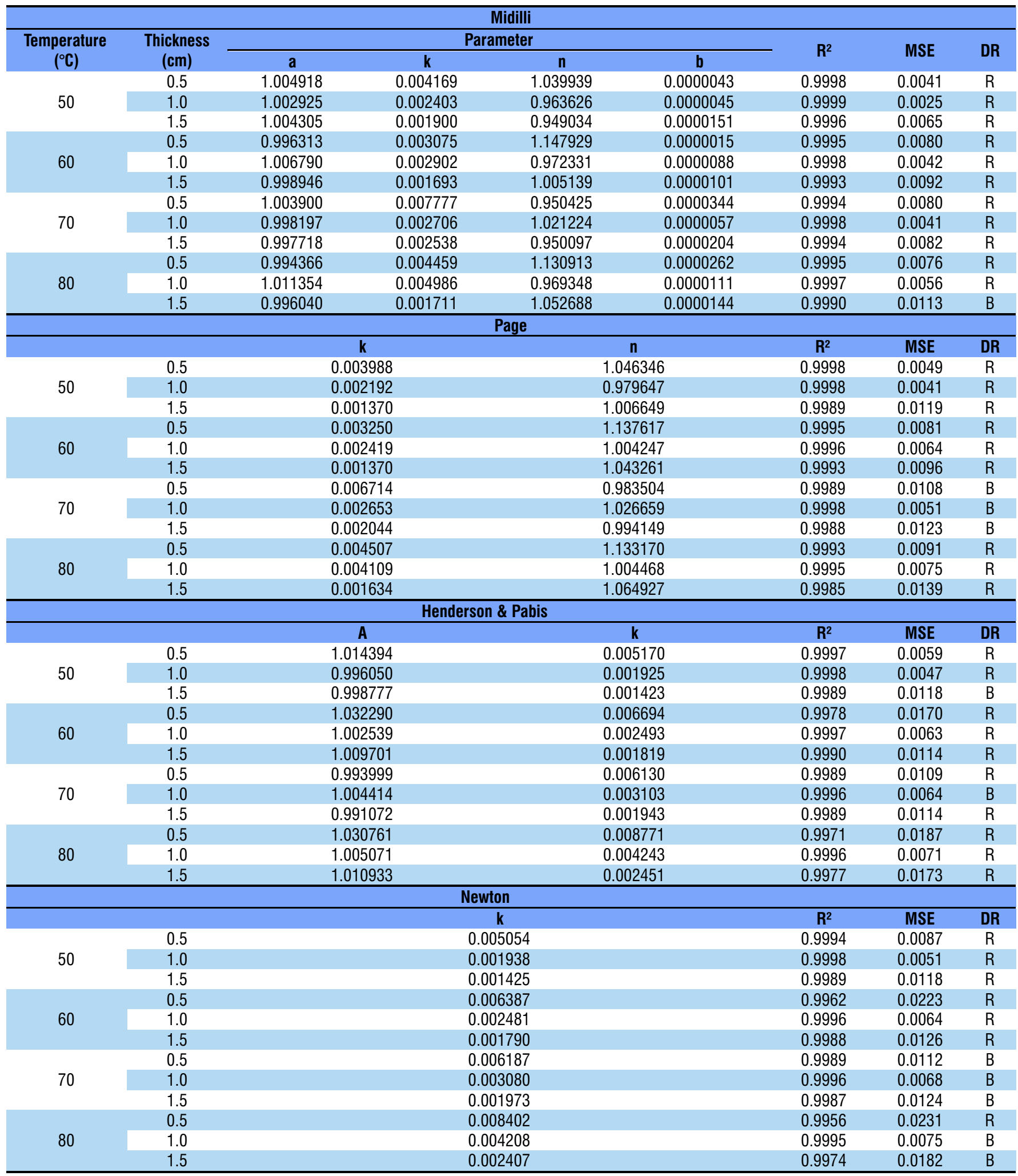

R - Random; B - Biased

the experimental data of pequi pulp drying kinetics at different temperatures $\left(50,60,70\right.$ and $\left.80^{\circ} \mathrm{C}\right)$ and thicknesses $(0.5,1.0$ and $1.5 \mathrm{~cm}$ ) with the respective determination coefficients $\left(\mathrm{R}^{2}\right)$ and mean squared errors (MSE).

The Midilli model showed the best fit to the experimental data of pequi pulp drying at all temperatures and thicknesses, with the highest determination coefficients $\left(R^{2}\right)$ ranging between 0.9990 and 0.9999 , the lowest mean square errors (MSE) ranging between 0.0025 and 0.00113 , and random distribution of residuals, which indicates that this model satisfactorily represents the phenomenon of pequi pulp drying.

The mathematical models of Page, Henderson \& Pabis and Newton also showed good fits to the experimental data of drying, with determination coefficients $\left(\mathrm{R}^{2}\right)$ higher than 0.98 
and mean square errors (MSE) below 0.03 , and can be used to predict pequi pulp drying kinetics. In general, all tested models fitted well to the experimental data and can be used to estimate the curves of pequi pulp drying kinetics, but the Midilli model showed the best results.

Regarding the parameter $\mathrm{k}$ (drying constant) of the models of Page, Henderson \& Pabis and Newton, it showed trend of decrease with the increment of layer thickness for a constant temperature. This behavior was expected because, with the increment in thickness, the drying rate decreases and, consequently, $\mathrm{k}$ also decreases. The phenomenon of reduction in the drying rate with the increment in thickness must be mostly related to the resistance found by the moisture in the migration from the inside to the surface of the sample (Pires et al., 2014). For the model of Newton, there was a trend of increase in $\mathrm{k}$ with the increment of temperature, for the studied thicknesses. Corrêa et al. (2010) dried coffee and observed that the drying constant $\mathrm{k}$ increases with the increment of temperature, since higher temperatures lead to higher drying rates.

The $\mathrm{k}$ value depends on the type of product, temperature and relative air humidity (Carlesso et al., 2007). The values of this parameter for the Page model are within the range from 0.00137 to $0.00671 \mathrm{~min}^{-1}$, for Newton between 0.00142 and $0.00840 \mathrm{~min}^{-1}$, and for Henderson \& Pabis from 0.00142 to $0.00877 \mathrm{~min}^{-1}$. Lower $\mathrm{k}$ values were found by Sousa et al. (2011)

A.
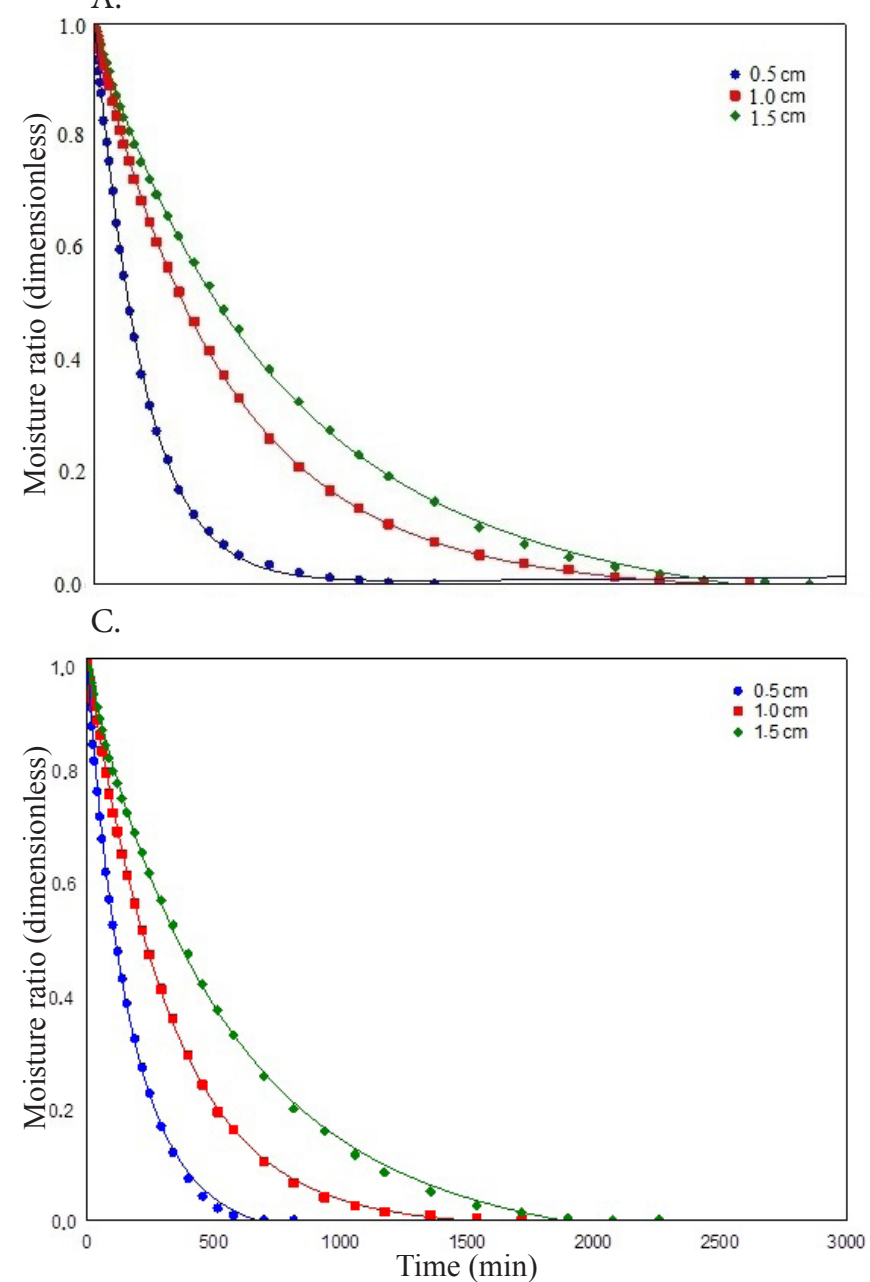

Figure 1. Curves of pequi pulp drying kinetics fitted with the Midilli model at temperatures of 50 (A), 60 (B), 70 (C) and $80{ }^{\circ} \mathrm{C}(\mathrm{D})$ in the mathematical modeling of 'oiti' pulp drying kinetics at temperatures of 50,60 and $70^{\circ} \mathrm{C}$, for the models of Midilli and Page, with $\mathrm{k}$ values from 0.0001 to $0.0007 \mathrm{~min}^{-1}$ for the former and from 0.0002 to $0.0006 \mathrm{~min}^{-1}$ for the latter.

The constant $\mathrm{n}$ of the models of Midilli and Page did not show defined trend with the increase of temperature and thickness, exhibiting values from 0.949034 to 1.147929 . Perez et al. (2013) claimed that the parameter $\mathrm{n}$ is related to the internal resistance of the material to the drying. Values of $\mathrm{n}$ within this range were found by Baptestini et al. (2015), evaluating the thin-layer drying kinetics of soursop foam at temperatures of $40,50,60,70$ and $80^{\circ} \mathrm{C}$, air speed of $5.6 \mathrm{~m} \mathrm{~s}^{-1}$ and thickness of $0.5 \mathrm{~cm}$. These researchers observed values of $\mathrm{n}$ ranging between 0.9829 and 1.2400 for the Midilli model and between 1.0536 and 1.2340 for the Page model, with no defined trend with the increase of temperature.

Values of $n$ close to the ones of the present study were reported by Munhoz et al. (2014) evaluating the drying kinetics of 'bocaiuva' at temperatures of 60 and $70{ }^{\circ} \mathrm{C}$ with air speed of $0.5 \mathrm{~m} \mathrm{~s}^{-1}$, in which the Page model provided the best description of the drying, with $n$ values of 0.877 and 1.054 .

Figure 1 illustrates the curves fitted with the Midilli model to the experimental data of pequi pulp drying kinetics at temperatures of $50,60,70$ and $80^{\circ} \mathrm{C}$, and pulp layer thicknesses of $0.5,1.0$ and $1.5 \mathrm{~cm}$.

B.

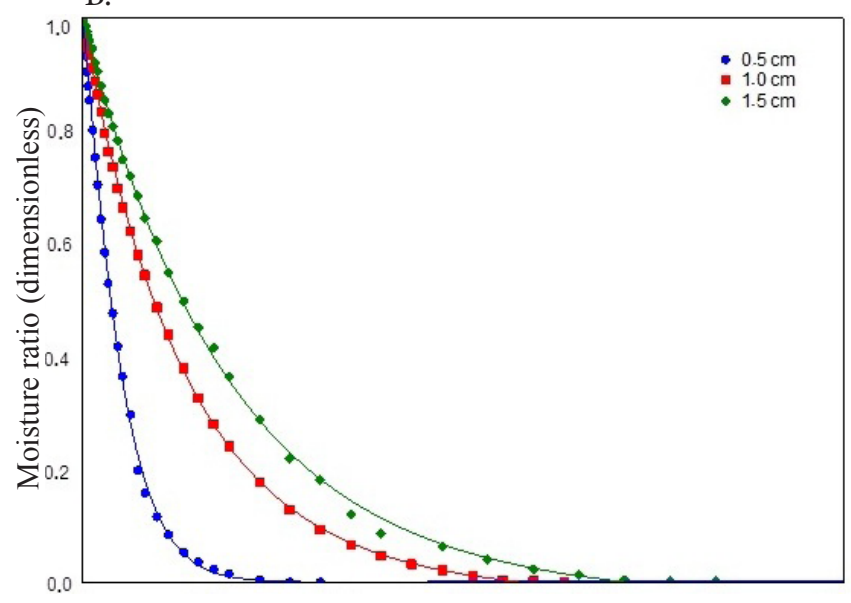

D.

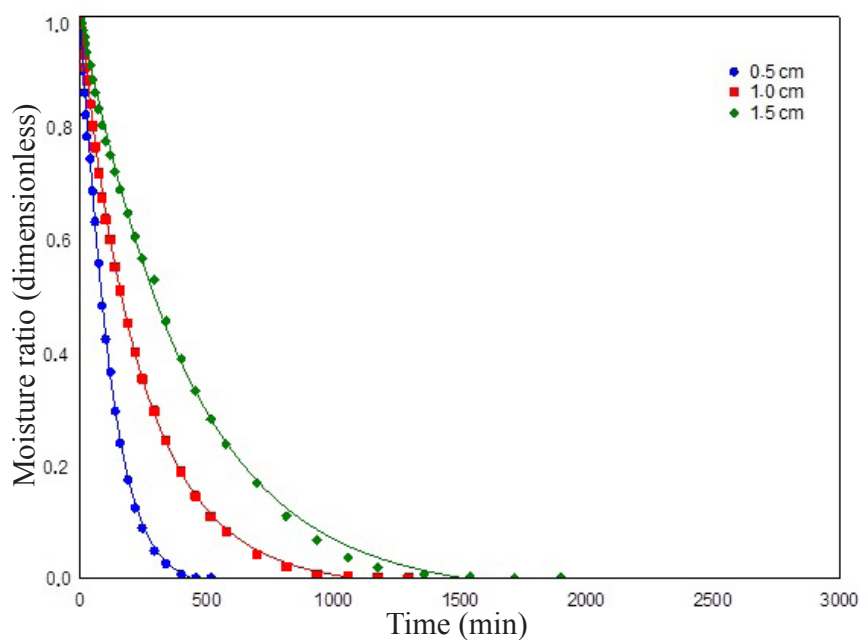


The Midilli model was considered as the one that best fitted to the experimental data in the prediction of pequi pulp drying curves. It was observed that the pequi pulp drying processes occurred in the period of decreasing rate. This period is driven by the diffusion mechanism, which consists in the removal of water from the inside of the pulp to the exposed surface. In this case, the internal heat transfer of the water conducts and fixes the drying rate (Perez et al., 2013; Baptestini et al., 2015).

For pequi pulp drying at temperatures of 50, 60, 70 and $80{ }^{\circ} \mathrm{C}$ (Figure 1), there was influence of pulp layer thickness and the drying time increased as thickness increased. Water losses are higher in the beginning of the drying process, after which the losses decrease with consequent reduction in the drying rate. A similar behavior was observed by Galdino et al. (2016) in the foam-mat drying of atemoya pulp at different temperatures $\left(60,70\right.$ and $\left.80^{\circ} \mathrm{C}\right)$ and thicknesses $(0.5,1.0$ and $1.5 \mathrm{~cm})$.

Table 3 shows the mean values of effective diffusivity $\left(D_{e f}\right)$, obtained in the pequi pulp drying with thicknesses of $0.5,1.0$ and $1.5 \mathrm{~cm}$ at temperatures of $50,60,70$ and $80^{\circ} \mathrm{C}$.

The effective diffusivity of pequi pulp under the different drying conditions varied from $0.93 \times 10^{-8}$ to $3.93 \times 10^{-8} \mathrm{~m}^{2} \mathrm{~s}^{-1}$. The values of effective diffusivity obtained in the present study were on the order of $10^{-8}$. Wilson et al. (2012) evaluated the effective diffusivity of mango pulp powder at different temperatures $\left(65,75\right.$ and $\left.85^{\circ} \mathrm{C}\right)$ and observed a variation from 1.53 to $2.63 \times 10^{-8} \mathrm{~m}^{2} \mathrm{~s}^{-1}$. Kadam \& Balasubramanian (2011) evaluated the effective diffusivity of tomato pulp powder dried at temperatures of 60,65 and $70{ }^{\circ} \mathrm{C}$ added of albumin $(5,10$ and $15 \%$ ), whose values were within the range from 2.026 to $3.039 \times 10^{-8} \mathrm{~m}^{2} \mathrm{~s}^{-1}$; these results are consistent with those found for pequi pulp powder.

There is a trend of increase in the effective diffusivity with the increment of pulp layer thickness and with the increment in temperature. The effective diffusivity is influenced by the temperature and drying air speed. The increase of these parameters causes increment in the effective diffusivity, because it directly influences the removal of water from the product (Silva et al., 2009; Deamici et al., 2016).

In general, with the increase of temperature, there is an increment in the drying rate and, consequently, in the effective

Table 3. Mean values of effective diffusivity $\left(D_{\text {ef }}\right)$ obtained in the pequi pulp drying with thicknesses of $0.5,1.0$ and $1.5 \mathrm{~cm}$ at temperatures of $50,60,70$ and $80{ }^{\circ} \mathrm{C}$ and their respective determination coefficients $\left(R^{2}\right)$

\begin{tabular}{|c|c|c|c|}
\hline $\begin{array}{c}\text { Temperature } \\
\left({ }^{\circ} \mathrm{C}\right)\end{array}$ & $\begin{array}{l}\text { Thickness } \\
\text { (cm) }\end{array}$ & $\begin{array}{c}D_{\text {ef }} \\
\left(x 10^{-8} \mathrm{~m}^{2} \mathrm{~s}^{-1}\right)\end{array}$ & $\mathbf{R}^{2}$ \\
\hline \multirow{3}{*}{50} & 0.5 & 0.93 & 0.9435 \\
\hline & 1.0 & 1.38 & 0.9409 \\
\hline & 1.5 & 2.31 & 0.9287 \\
\hline \multirow{3}{*}{60} & 0.5 & 1.20 & 0.9316 \\
\hline & 1.0 & 1.79 & 0.9393 \\
\hline & 1.5 & 2.91 & 0.9237 \\
\hline \multirow{3}{*}{70} & 0.5 & 1.14 & 0.9524 \\
\hline & 1.0 & 2.22 & 0.9369 \\
\hline & 1.5 & 3.18 & 0.9371 \\
\hline \multirow{3}{*}{80} & 0.5 & 1.59 & 0.9285 \\
\hline & 1.0 & 3.06 & 0.9424 \\
\hline & 1.5 & 3.93 & 0.9241 \\
\hline
\end{tabular}

diffusivity, thus increasing the efficiency of water removal from the pequi pulp. Santos et al. (2014) demonstrated that this behavior occurs due to the increase in the vibration level of the water molecules, contributing to a greater diffusion of the fluid material. Another hypothesis for this behavior is that, with the increment of temperature, water viscosity decreases, favoring the movement of this fluid from the product to the drying air, leading to the increase in the diffusion of the water of the product (Goneli et al., 2014). The increment of temperature increases the effective diffusivity also because of the increase in the vapor pressure inside the sample (Gupta \& Alam, 2014). The determination coefficients $\left(\mathrm{R}^{2}\right)$ were higher than 0.91 , demonstrating that the Fick's model for a flat plate satisfactorily fitted to the experimental data.

\section{Conclusions}

1. The Midilli model showed the best fit to the data, highest determination coefficients and lowest mean square errors.

2. The effective diffusivity increased with the increment in drying temperature and with the increment in pulp layer thickness.

\section{ACKNOWLeDgments}

To the Coordination for the Improvement of Higher Education Personnel (CAPES), for the financial support to the research.

\section{Literature Cited}

Alexandre, H. V.; Figueirêdo, R. M. F. de; Queiroz, A. J. de M. Isotermas de adsorção de umidade da pitanga em pó. Revista de Biologia e Ciências da Terra, v.7, p.11-20, 2007.

Aquino, L. P.; Ferrua, F. Q.; Borges, S. V.; Antoniassi, R.; Correa, J. L. G.; Cirillo, M. A. Influência da secagem do pequi (Caryocar brasiliense Camb.) na qualidade do óleo extraído. Revista Ciência e Tecnologia de Alimentos, v.29, p.354-357, 2009. https://doi. org/10.1590/S0101-20612009000200018

Baptestini, F. M.; Corrêa, P. C.; Junqueira, M. S.; Ramos, A. M.; Vanegas, J. D. B.; Costa, C. F. Modelagem matemática da secagem de espuma de graviola. Revista Brasileira de Engenharia Agrícola e Ambiental, v.19, p.1203-1208, 2015. https://doi.org/10.1590/18071929/agriambi.v19n12p1203-1208

Carlesso, V. de O.; Berbert, P. A.; Silva, R. F. da; Detmann, E. Avaliação de modelos de secagem em camada fina de sementes de maracujá amarelo. Revista Brasileira de Sementes, v.29, p.28-37, 2007. https://doi.org/10.1590/S0101-31222007000200005

Carlos, L.; Venturin, N.; Macedo, R. L. G.; Higashikawa, E. M.; Garcia, M. B.; Farias, E. de S. Crescimento e nutrição mineral de mudas de pequi sob efeito da omissão de nutrientes. Ciência Florestal, v.24, p.13-21, 2014. https://doi.org/10.5902/1980509813318

Corrêa, P. C.; Oliveira, G. H. H.; Botelho, F. M.; Goneli, A. L. D.; Carvalho, F. M. Modelagem matemática e determinação das propriedades termodinâmicas do café (Coffea arabica L.) durante o processo de secagem. Revista Ceres, v.57, p.595-601, 2010. https://doi.org/10.1590/S0034-737X2010000500005 
Damiani, C.; Almeida, T. L. de; Costa, N. V.; Medeiros, N. X. de; Silva, A. G. de M. e; Silva, F. A. da; Lage, M. E.; Becker, F. S. Perfil de ácidos graxos e fatores antinutricionais de amêndoas de pequi crua e torrada. Pesquisa Agropecuária Tropical, v.43, p.71-78, 2013. https://doi.org/10.1590/S1983-40632013000100004

Deamici, K. M.; Oliveira, L. C. de; Rosa, G. S. da; Oliveira, E. G. de. Drying kinetics of fermented grape pomace: Determination of moisture effective diffusivity. Revista Brasileira de Engenharia Agrícola e Ambiental, v.20, p.763-768, 2016. https://doi. org/10.1590/1807-1929/agriambi.v20n8p763-768

Dionello, R. G.; Berbert, P. A.; Molina, M. A. B. de; Pereira, R. de C.; Viana, A. P.; Carlesso, V. de O. Secagem de fatias de abacaxi in natura e pré-desidratadas por imersão-impregnação: Cinética e avaliação de modelos. Ciência e Tecnologia de Alimentos, v.29, p.232-240, 2009. https://doi.org/10.1590/S010120612009000100036

Galdino, P. O.; Figueirêdo, R. M. F. de; Queiroz, A. J. de M.; Galdino, P. O. Drying kinetics of atemoya pulp. Revista Brasileira de Engenharia Agrícola e Ambiental, v.20, p.672-677, 2016. https:// doi.org/10.1590/1807-1929/agriambi.v20n7p672-677

Goneli, A. L. D.; Vieira, M. do C.; Vilhasanti, H. da C. B.; Gonçalves, A. A. Modelagem matemática e difusividade efetiva de folhas de aroeira durante a secagem. Pesquisa Agropecuária Tropical, v.44, p.56- 64, 2014. https://doi.org/10.1590/S198340632014000100005

Gupta, K.; Alam, M. S. Mass and color kinetics of foamed and non foamed grape concentrate during convective drying process: A comparative study. Journal of Engineering and Technology Research, v.6, p.48-67, 2014. https://doi.org/10.5897/ JETR2014.0350

Kadam, D. M.; Balasubramanian, S. Foam mat drying of tomato juice. Journal of Food Processing and Preservation, v.35, p.488-495, 2011. https://doi.org/10.1111/j.1745-4549.2010.00492.x

Munhoz, C. L.; Sanjinez-Argandoña, E. J.; Campagnolli, R.; Macedo, M. L. R. Drying of the kernel and fresh and osmotically dehydrated bocaiuva pulps. Acta Scientiarum. Technology, v.36, p.165-170, 2014. https://doi.org/10.4025/16843
Oliveira, M. E. B. de; Guerra, N. B.; Maia, A. de H. N.; Alves, R. E.; Matos, N. M. dos S.; Sampaio, F. G. M.; Lopes, M. M. T. Características químicas e físico-químicas de pequis da Chapada do Araripe, Ceará. Revista Brasileira de Fruticultura, v.32, p.114-125, 2010. https://doi. org/10.1590/S0100-29452010005000030

Perez, L. G.; Oliveira, F. M. N. de; Andrade, J. S.; Moreira Filho, M. Cinética de secagem da polpa cupuaçu (Theobroma grandiflorum) pré desidratada por imersão-impregnação. Revista Ciência Agronômica, v.44, p.102-106, 2013. https://doi.org/10.1590/S180666902013000100013

Pires, V. C. F.; Silva, F. L. H. da; Souza, R. M. S. Parâmetros da secagem da banana pacovan e caracterização físico-química da farinha de banana verde. Revista Verde de Agroecologia e Desenvolvimento Sustentável, v.9, p.197-209, 2014. https://doi.org/10.18378/rvads.v9i1.2577

Resende, I. L. de M.; Santos, F. P. dos; Chaves, L. J.; Nascimento, J. L. do. Estrutura etária de populações de Mauritia flexuosa L. F. (Arecaceae) de veredas da região central de Goiás, Brasil. Revista Árvore, v.36, p.103-112, 2012. https://doi.org/10.1590/S010067622012000100012

Santos, D. da C.; Queiroz, A. J. de M.; Figueirêdo, R. M. F. de; Oliveira, E. N. A. de. Difusividade efetiva e energia de ativação em farinhas de grãos residuais de urucum. Comunicata Scientiae, v.5, p.75-82, 2014.

Sousa, F. C. de; Sousa, E. P. de; Silva, L. M. de M.; Martins, J. J. A.; Gomes, J. P.; Rocha, A. P. T. da. Modelagem matemática para descrição da cinética de secagem de polpa de oiti. Revista Educação Agrícola Superior, v.26, p.108-112, 2011.

Silva, A. S.; Melo, K. dos S.; Alves, N. M. C.; Fernandes, T. K. da S.; Farias, P. de A. Cinética de secagem em camada fina da banana maçã em secador de leito fixo. Revista Brasileira de Produtos Agroindustriais, v.11, p.129-136, 2009. https://doi.org/10.15871/1517-8595/rbpa. v11n2p129-136

Statsoft. Statistica for Window - Computer programa manual. Versão 7.0 Tulsa: Statsoft Inc., 2007.

Wilson, R. A.; Kadam, D. M.; Chadha, S.; Sharma, M. Foam mat drying characteristics of mango pulp. International Journal of Food Science and Nutrition Engineering, v.2, p.63-69, 2012. https://doi. org/10.5923/j.food.20120204.03 